\title{
Mass aggregations of Bibio pomonae (Insecta: Diptera: Bibionidae), an indication of climate change?
}

\author{
Tore Qvenild' and Sigurd Rognerud²
}

Qvenild T and Rognerud S. 2017. Mass aggregations of Bibio pomonae (Insecta: Diptera: Bibionidae), an indication of climate change? Fauna norvegica 37: 1-12.

Examination of stomach contents of the brown trout is a sensitive method to evaluate the animals occurring in a lake and its surroundings. Yearly test fishing from Lake Sandvatn at the Hardangervidda Mountain plateau in August has shown regular occurrence of Bibio pomonae in the brown trout stomachs every third year since 2001. The stomach fullness and selectivity for other food items is influenced by the local weather conditions, but in calm and sunny weather, mass aggregation of $B$. pomonae are reflected by high stomach fullness and the brown trout predate $B$. pomonae selectively. The stomach fullness with $B$. pomonae may give a significant measure of the mass aggregation phenomena in such periods. On the Hardangervidda Mountain plateau mass aggregation have been observed regularly every third year since 2001. Mass aggregations elsewhere on the southern part of the Scandinavian Peninsula seem to follow the same pattern, but with a one-year delay in the northern part. Our results substantiate that mass aggregations of $B$. pomonae seem to be an irregular phenomenon in the previous century. In 2016 mass aggregation of $B$. pomonae was observed in the southern part of the Norwegian mountain range with its maximum abundance in the lower alpine zone. The abundance seems to have extended its maximum from the subalpine zone into the lower alpine zone. Mass aggregations were observed $1678 \mathrm{~m}$ a.s.1., $318 \mathrm{~m}$ higher up than previously recorded. In 2016 B. pomonae was also recorded earlier than ever before. Climate change may be a driver of the regular mass aggregations, the apparently increase in strength, the elevation of the abundance maximum, the new extreme altitude swarming, and the early hatchings seen after 2000 .

doi: 10.5324/fn.v37i0.2194. Received: 2017-01-12. Accepted: 2017-04-27. Published online: 2017-06-10. ISSN: $1891-5396$ (electronic).

Keywords: Brown trout feeding, Bibio pomonae, mass aggregations, climate change

1. County Governor of Hedmark, Parkgata 36, NO-2317 Hamar, Norway.

2. Norwegian Institute for Water Research (NIVA), Sandvikavegen 59, NO-2312 Ottestad, Norway.

Corresponding author: Tore Qvenild

E-mail:fmhetq@fylkesmannen.no 


\section{INTRODUCTION}

The genus Bibio is an almost cosmopolitan group of flies. In Norway fourteen species are known. The species Bibio pomonae (Fabricius, 1775) is generally distributed and common throughout Norway. Its present status was summarized by Skartveit (1995). B. pomonae normally reaches its maximum abundance in the subalpine zone, but it generally extends its distribution into the lower alpine zone (Greve et al. 1984; Skartveit 1995).

Bibio pomonae is quite conspicuous due to its large size and bright red femorae. Thus $B$. pomonae is the species which has most commonly been noticed (Skartveit \& Greve 1995). The flies can sometimes be seen swarming over water and in periods with mass aggregations it can be a significant food supply for the brown trout. The fly is well known among anglers and several kinds of fishing flies are available. Despite its obvious importance as fish food organism when swarming, and the importance of imitating it for anglers in these periods, there are no known references about the frequency of mass aggregation periods.

The brown trout is an opportunistic feeder and the diet changes with food availability. Examination of stomach content of the brown trout may be a sensitive method to evaluate the animals occurring in a lake and its surroundings (Fjellheim et al. 2007). From Lake Sandvatn at the Hardangervidda Mountain plateau yearly test fishing in August has shown regular occurrence of $B$. pomonae in the stomachs of brown trout every third year since 2001 .

Early in the ice-free period chironomid larvae and pupae, trichopterans, other insect larvae and Gammarus lacustris are dominant food items. From July to September this shifts to a diet dominated by the crustaceans Eurycercus lamellatus, Lepidurus arcticus and Gammarus lacustris. Gastropoda, especially Lymnea peregra and bivalvia (Pisidae sp.), and to some extent terrestrial insects, may also be of significance. In years with mass aggregations of $B$. pomonae the brown trout diet reflects this event and the stomach fullness may be an indicator of the mass aggregation strength.

The distribution and flight periods of $B$. pomonae were discussed in detail by Skartveit (1995). However, only a few events of mass aggregation were noted. Our studies indicated that mass aggregations were well known despite the sparse information of the phenomena. In the $21^{\text {st }}$ century this phenomenon apparently has increased. Because of the regular occurrence in Lake Sandvatn we assumed 2016 to be a mass aggregation summer. We therefore prepared a detailed mapping of an expected event.

In this paper, we will discuss the frequency of mass aggregations monitored by its significance as fish food supply in Lake Sandvatn on the Hardangervidda Mountain plateau. It was also one of our main tasks to evaluate other characteristics of the mass aggregation phenomena; is it a local and patchy phenomenon or does it occur synchronously to a broader extent? Hence, our results from this area are compared to similar observations elsewhere on the Scandinavian Peninsula.

Temperature affects the development and growth rate of the larvae (Skartveit \& Solhøy 1997). A series of spring-summer temperatures (April-August) for the period 1734-2003 showed a temperature increase in the $20^{\text {th }}$ century (Nordli et al. 2003). The increase in temperature seems to have occurred in abrupt shifts. Since the last shift in the 1920s the temperature remained high, but did not increase above the maximum of the 1940s until recently. Since 2000 the spring-summers have remained at a higher level. The more regular mass occurrences of $B$. pomonae so far in the $21^{\text {st }}$ century may reflect this shift. Our results are discussed in the context of the ongoing climate change.

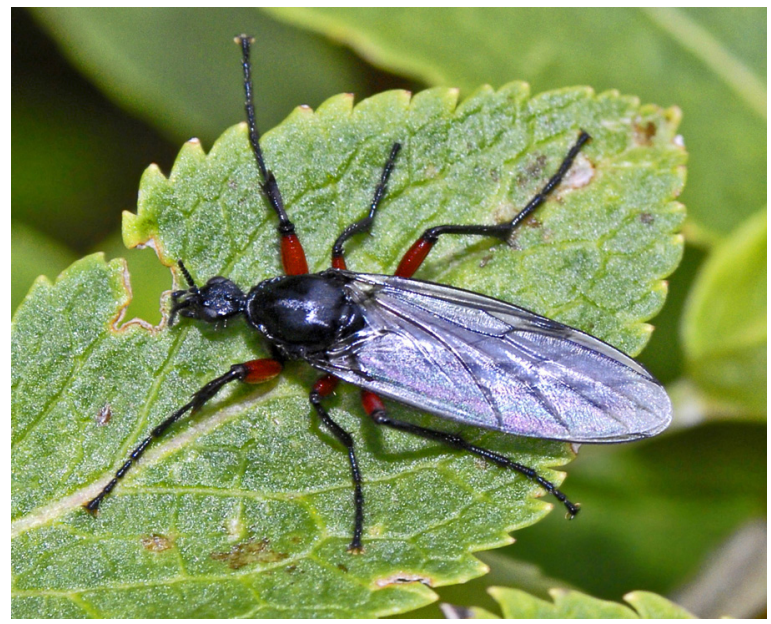

Figure I. Bibio pomonae is quite conspicuous due to its large size, long legs and bright red femorae. Photo: Knut Holager.

\section{MATERIAL AND METHODS}

\section{Study area}

Lake Sandvatn, $1112 \mathrm{~m}$ a.s.l., is a middle-sized lake in the River Kvenna watercourse, the upper part of the Skien watercourse system (Figure 2). To optimize the management of the lakes in the Laagefjeld part of Kvenna, Lake Sandvatn has been test fished in mid-August (8 - 19 August) regularly since 2001 (except 2003). Most lakes on the Hardangervidda Mountain plateau are situated between 800 and $1500 \mathrm{~m}$ a.s.l. Most of the plateau is thus situated in the sub alpine birch zone and the lower alpine zone (http://www.agropub.no/id/9644).

Kvenna is the biggest river on the $8000 \mathrm{~km}^{2}$ Hardangervidda Mountain plateau, running from the sources in the west, to its outflow in Lake Møsvatn reservoir in the east $(60 \mathrm{~km}$, average runoff $30 \mathrm{~m}^{3} / \mathrm{s}$ at the outflow at Mogen). The lake surface area of Lake Sandvatn is $1,57 \mathrm{~km}^{2}$, maximum depth $15 \mathrm{~m}$ and mean depth $2,6 \mathrm{~m}$.

Brown trout is the only fish species in the upper part of the river. The main food items are Chironomidae and Trichoptera, and lake-dwelling organism as Lymnea peregra and crustaceans like the notostrachan Lepidurus arcticus, the amphipod 


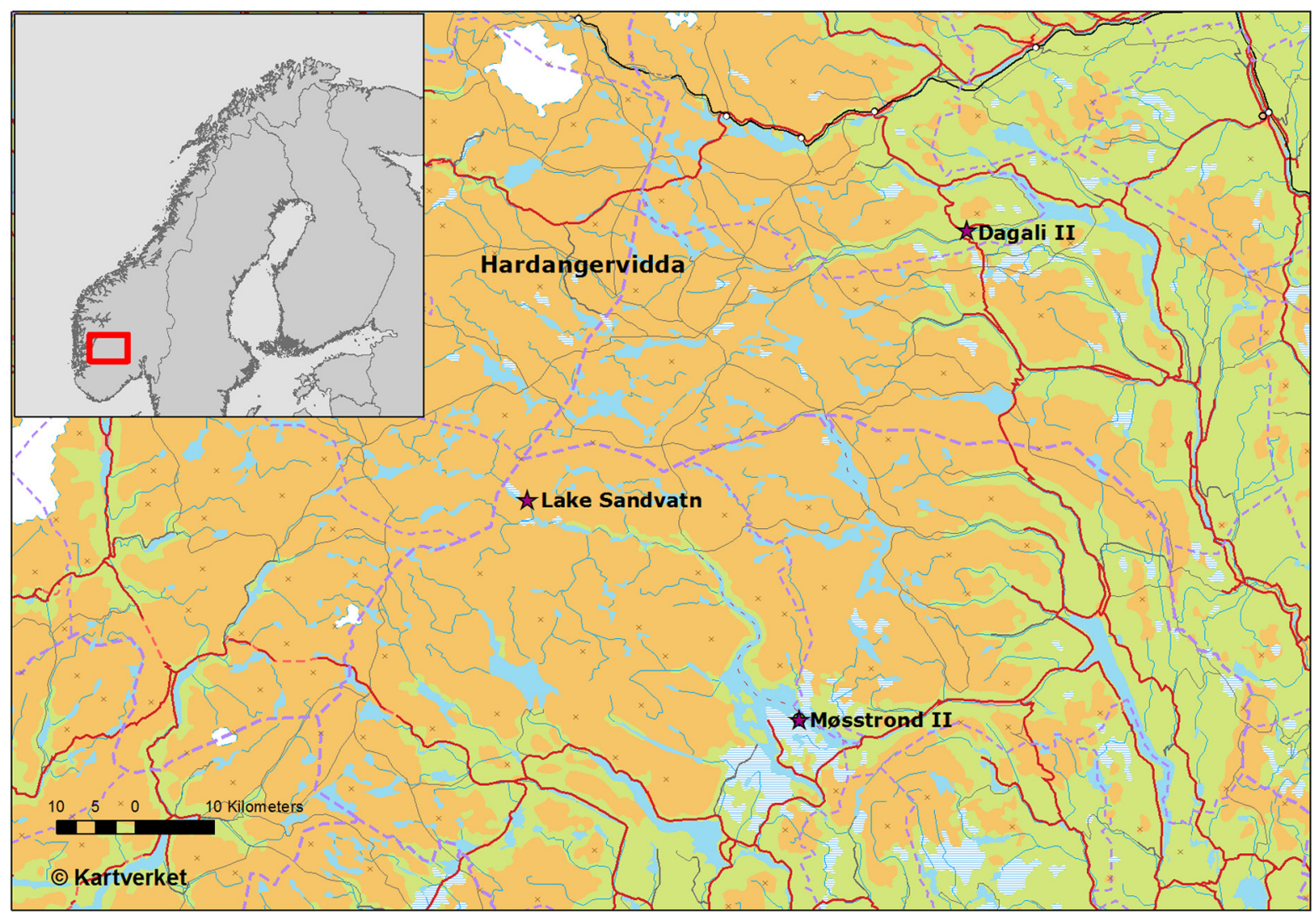

Figure 2. Map of the Hardangervidda Mountain plateau. Lake Sandvatn $\left(60.0541^{\circ} \mathrm{N}, 7.5122^{\circ} \mathrm{E}\right)$ and the weather stations Dagali II $\left(60.4113^{\circ} \mathrm{N}\right.$, $\left.8.4444^{\circ} \mathrm{E}\right)$ and Møsstrond II $\left(59.8397^{\circ} \mathrm{N}, 8.1785^{\circ} \mathrm{E}\right)$ are indicated. The Norwegian Mapping Authority CC BY 4.0.

Gammarus lacustris and the chydorid Eurycercus lamellatus. B. pomonae is well documented from the Hardangervidda Mountain plateau (Skartveit 1995; Skartveit \& Greve 1995).

\section{Methods}

We have used a semi quantitative method where the volume percent of each food organism is estimated separately by two skilled observers which reflect the "point method" of Hynes (1950). The stomach fullness is determined on a scale from 0 - 5 , where $=0$ is empty and $=5$ is full stomach. From this the frequencies of fish with different items eaten can also be calculated.

In the period 2001-2016 we have analyzed 2963 stomachs (Table 1). B. pomonae has been observed regularly in Lake Sandvatn in 2004, 2007, 2010, 2013 and 2016. In these years 956 stomachs have been analyzed and $B$. pomonae is a significant item in 248 of these.

Mass aggregations elsewhere on the Scandinavian Peninsula were mapped by collecting data from many different sources like scientific papers and reports, magazines of sport fishing, google search and personal communications. Google search using Latin name and Norwegian synonyms as keywords gave results. For a comparison with Skartveit (1995) the different observations are mapped on EIS maps (European Invertebrate Survey; http://www.entomologi.no/div/EIS.html).
As we expected a year with mass aggregations in 2016 we prepared a detailed mapping of the event. We primarily used our own network, but the expected event was also announced in a sport fishery magazine (Qvenild 2016) and in a sport fishery blog (http://www.larsoglars.no/). We received 83 individual reports throughout the Scandinavian Peninsula. The reports were sorted in accordance with the observer's statements as NEGATIVE, SINGLE SPECIES, MODERATE SWARMING or MASS SWARMING. The different localities were grouped according to the tree line (http://www.agropub.no/id/9644). If it is located higher than the tree line we have defined it as lower alpine or alpine zone, or beneath the tree line as subalpine zone. The altitude of the tree line varies both in an east west gradient and especially in a north south gradient.

In an extended survey in 2016, 29 fishing teams in the lower part of the Kvenna watercourse were included to evaluate the flight time of $B$. pomonae. We compared the results with the continuous observations made by Jarle Viskjer at the Litlos tourist station at Hardangervidda Mountain plateau $1170 \mathrm{~m}$ a.s.l. in the upper part of Kvenna.

\section{Climate at the Hardangervidda Mountain plateau}

A series of spring-summer temperatures (April-August) called the Vestlandet series, was reconstructed for the period 17342003 for western Norway (Nordli et al. 2003). It correlates well 
with the Austlandet and Uppsala series. The Vestlandet series was prolonged to 2016 (eKlima, met.no).

The spring-summer reconstruction showed a temperature increase in the $20^{\text {th }}$ century. The increase in temperature often seems to have occurred in abrupt shifts, as in the 1810s and the 1920s. Since the last shift the temperature remained high, but did not increase above the maximum of the 1940s until recently. Since 2000 the spring-summers have remained at a higher level. The average spring-summers after 2000 at Bergen station during the years $2000-2016\left(12.6 \pm 0.8^{\circ} \mathrm{C}\right)$ were significantly elevated compared to the previous 30 -years normal $\left(11.7 \pm 0.6^{\circ} \mathrm{C}\right.$ ) (Wilcoxon signed rank; $\mathrm{p}=<0.001$ ). The same phenomenon can also be observed at Møsstrond II (7.2 \pm $0.7^{\circ} \mathrm{C}$ vs. $6.3 \pm 0.6^{\circ} \mathrm{C}, \mathrm{p}=0.001$ ).

The spring-summer 2002 is the warmest $\left(14.1^{\circ} \mathrm{C}\right)$ in the period 1743-2016. This was followed by the spring-summer $2014\left(13.9^{\circ} \mathrm{C}\right)$ and 1947, 2003, 2008 and $2009\left(13.4^{\circ} \mathrm{C}\right)$. The warmest spring-summers occurred mainly after 1930 . The spring-summers of 1930, 1933 and 1937 were also warmer than $13^{\circ} \mathrm{C}$. All the records in the $21^{\text {st }}$ century were higher than the Bergen normal (1961-1990) except the spring-summer 2015.

Two weather stations representative for the Hardangervidda Mountain plateau are available at Dagali and Møsstrond (met. no, Figure 2). The Bergen instrumental series correlates well with the local station Møsstrond II $\left(\mathrm{r}^{2}=0.76, \mathrm{p}<0.0001\right)$, Bergen being $5.3^{\circ} \mathrm{C}$ warmer. Møsstrond II (977 $\mathrm{m}$ a.s.l.) correlates well with Dagali II ( $828 \mathrm{~m}$ a.s.l.), Dagali II being $0.40^{\circ} \mathrm{C}$ warmer $\left(\mathrm{r}^{2}\right.$ $=0.9572, p<0.0001)$. The temperature at other localities at the Hardangervidda Mountain plateau also shows high correlations (Rognerud et al. 2006).

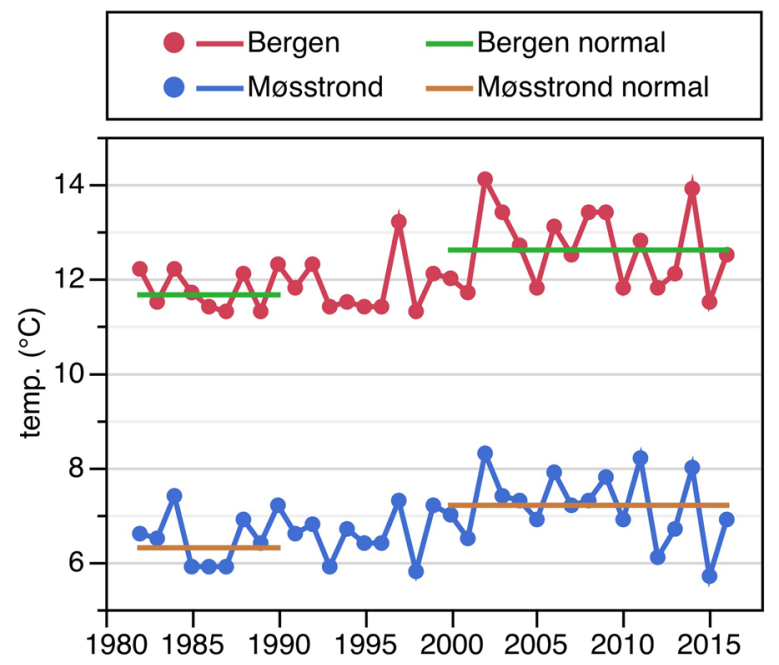

Figure 3. The spring-summers temperature (AMJJA) at Bergen during the years $2000-2016\left(12.6 \pm 0.8^{\circ} \mathrm{C}\right)$ was significantly elevated compared to the previous 30-years normal 1961-1990 $\left(11.7 \pm 0.6^{\circ} \mathrm{C}\right)$ (Wilcoxon signed rank; $\left.\mathrm{p}=<0.001\right)$. The same phenomenon can also be observed at Møsstrond II $\left(7.2 \pm 0.7^{\circ} \mathrm{C}\right.$ vs. $\left.6.3 \pm 0.6^{\circ} \mathrm{C}, \mathrm{p}=0.001\right)$.
The good correlation between the local weather stations and the Bergen instrumental series can thus be used to evaluate the long term climatic variability at Hardangervidda Mountain plateau. Because of the good correlation of the Vestlandet series with the Austlandet and Uppsala series, we assume that the main changes in temperature in the $20^{\text {th }}$ and $21^{\text {st }}$ centuries also reflects the southern part of the Norwegian mountain range.

\section{RESULTS}

\section{Mass aggregations of Bibio pomonae on the Scandinavian Peninsula}

Adult specimens of $B$. pomonae are easily caught because of their awkwardness and because they quite often are abundant when present, and B. pomonae is commonly noticed (Skartveit \& Greve 1995). Nevertheless, astonishing few references are noted in scientific journals or in the trivial literature, and only a few researchers have dealt with this species.

Schøyen (1884) noted an exceptional event in a lake in Nordland in 1881 where the trout grazed heavily upon the wrecked flies. In 1883 he reported mass occurrence from the lower location Odalen in Hedmark (129 m a.s.l.).

In 1938 there was observed heavy mass swarming at Lake Tunnsjøen in Nord-Trøndelag (Anon 1938). The event was verified by the Royal Norwegian Society of Sciences and Letters (DKNVS 1938). DKNVS received information about a similar event in 1935 from Lake Tunnsjøen and Lake Limingen and swarming should also have occurred elsewhere but not to the same extent as at the lakes specified. Earlier years this species should not have been noted (Anon. 1938). In 1938 B. pomonae was also observed in the Jotunheimen area but not as mass aggregations (Baashus-Jessen 1938). It was hypothesized that the cold weather in this southern part compared to the Trøndelag region could be an explanation. In 1944 Andersson (1944) reported on an intense mass swarming from Jokkmokk in northern Sweden. In 1950 mass swarming was reported from the subalpine region from the southeastern part of Norway (Anon 1950). From Sweden, we have a record from Torneträsk in 1968 (Gösta Kjellberg, pers. comm.).

The first event of mass aggregation experienced by the authors was from the western part of the Hardangervidda Mountain plateau in August 1972 (Viveli-Stavali). In 1974 we have two reports on mass aggregations, one from Jølster (Harald Sægrov, pers. comm.) in Hordaland and one from Lake Unkervatnet in Nordland (own obs.; Jan Ivar Koksvik, pers.comm.). In Oppdal mass swarming was reported from Stroplsjøen and Vinstradalen in the 1980s (Skartveit 1995). Skartveit (op.cit.) also reported mass occurrences in the 1980s at Mjølfjell at Voss, and in Kirkesdalen in Målselv in 1992.

Our studies in Lake Sandvatn showed a regular pattern of mass occurrences every third year since 2001. We therefore searched for verification of similar events in other areas and localities. In 2001 mass swarming was recorded in the Tynset 
area in Hedmark (Gösta Kjellberg, pers. comm.) in addition to our own registration from Lake Brisketjørna. In 2004 we also recorded $B$. pomonae in brown trout stomachs in a tributary to Kvenna (Lake Kringlesjå in the Skvetta tributary). It was also recorded in Lake Pålsbufjorden (Brabrand et al. 2005 ) and in Bygdin in Jotunheimen (Stein I. Johnsen, pers. comm.). A google-search gave an observation in Hemsedal. All observations are from the lower alpine zone in southern Norway.

In 2007 B. pomonae was observed in Lake Songa (Saltveit \& Brabrand 2008), in Lake Svartavatnet and Lake Svartavasstjørni (Fjellheim et al. 2008) on the Hardangervidda Mountain plateau in addition to Lake Sandvatn. A google-search also noted it from the Valdres region. All observations are from the lower alpine zone in southern Norway.

In 2010 B. pomonae was observed in two lakes (Lake Kollsvatn and Lake Litlosvatn) higher up in the Kvenna river system (Borgstrøm 2012, 2014) in addition to Lake Sandvatn. It was also reported from Øyerfjellet at Lillehammer 7-800 m a.s.l. (Øystein Aas, pers. comm.) and from Atna River $700 \mathrm{~m}$ a.s.l. (Jostein H. Lund, pers. comm.). A google-search gave a record from Hemsedal. The observations are from the subalpine or lower alpine zone in southern Norway.
In 2013 we got a note from Lake Skjerjavatn (Knut Holager, pers. comm.) on the Hardangervidda Mountain plateau in addition to Lake Sandvatn. A google-search gave an unspecific record somewhere else on the Hardangervidda Mountain plateau. Outside Hardangervidda B. pomonae was reported from Lake Tallsjøen (Jan Ivar Koksvik, pers. comm.), from the Folldal area (Bjørn Wegge, pers. comm.) and from river Glomma at Kvennan in Tolga (Hein van Aar, pers. comm.), all in Hedmark County, and from Tydal in the Røros region (Rollef Krabberød, pers. comm.). The observations are from the subalpine or lower alpine zone in southern Norway.

The records from 2001-2013 are all from the subalpine or the lower alpine zone in the central and southern part of Norway. A google-search gave additional information for the northern part of Norway and Sweden. In 2003 we have a note from Bardu in Troms. In 2005 we have two more records, one from Sulitjelma and one from Porsanger in Finmark. In 2008 we have notes from Rana, Troms and Finmark, and from Vaggotjälme in Sweden. From 2011 mass occurrences of $B$. pomonae was observed in Lake Unkervatnet in Nordland (Jan Ivar Koksvik, pers. comm.). A google-search gave additional records from northern part of Norway and Sweden (Ammarnäs and Arjeplog).

Table I. Bibio pomonae in the brown trout stomachs in Lake Sandvatn in the period 2001-2016.

\begin{tabular}{|c|c|c|c|c|c|c|c|}
\hline & Date & No stomachs & Stomach fullness & $\begin{array}{l}\text { Stomach fullness } \\
\text { B. pomonae }\end{array}$ & Empty stomachs \% & $\begin{array}{l}\text { B. pomonae } \\
\text { volume } \%\end{array}$ & $\begin{array}{l}\text { B. pomonae } \\
\text { frequency } \%\end{array}$ \\
\hline 2001 & $12-17$ Aug & 114 & 0.91 & $0^{1}$ & 67.5 & 0 & 0 \\
\hline 2002 & $12 \mathrm{Aug}$ & 76 & 1.96 & 0 & 34.2 & 0 & 0 \\
\hline \multicolumn{8}{|l|}{2003} \\
\hline 2004 & 16 Aug & 49 & 1.10 & $0.22(20 \%)$ & 42.9 & 19.6 & 12.2 \\
\hline 2005 & $15-17$ Aug & 155 & 0.75 & 0 & 55.5 & 0 & 0 \\
\hline 2006 & $14-16$ Aug & 111 & 1.24 & 0 & 39.6 & 0 & 0 \\
\hline 2007 & 27 Jun & 83 & 1.58 & 0 & 30.1 & 0 & 0 \\
\hline 2007 & $12-15$ Aug & 277 & 1.86 & $0.45(24 \%)$ & 32.1 & 24.0 & 22.0 \\
\hline 2007 & $30 \mathrm{Sep}$ & 46 & 1.20 & 0 & 34.8 & 0 & 0 \\
\hline 2008 & $10-11$ Aug & 269 & 1.07 & 0 & 49.1 & 0 & 0 \\
\hline 2008 & $28 \mathrm{Sep}$ & 33 & 1.21 & 0 & 27.3 & 0 & 0 \\
\hline 2009 & $11-14$ Aug & 252 & 1.42 & 0 & 40.9 & 0 & 0 \\
\hline 2010 & 26 Jun & 60 & 1.40 & 0 & 40.0 & 0 & 0 \\
\hline 2010 & 7 - 11 Aug & 193 & 2.46 & $0.82(33 \%)$ & 19.7 & 33.4 & 33.2 \\
\hline 2010 & 30 Sep & 75 & 1.35 & 0 & 42.7 & 0 & 0 \\
\hline 2011 & 13 - 19 Aug & 205 & 1.34 & 0 & 45.9 & 0 & 0 \\
\hline 2012 & $13-17$ Aug & 145 & 1.57 & 0 & 40.7 & 0 & 0 \\
\hline 2013 & 11 - 15 Aug & 214 & 2.07 & $0.34(16 \%)$ & 30.4 & 16.3 & 12.1 \\
\hline 2014 & $9-12$ Aug & 123 & 1.42 & 0 & 33.3 & 0 & 0 \\
\hline 2015 & 8. - 14. aug & 260 & 1.45 & 0 & 40.8 & 0 & 0 \\
\hline 2016 & 14.-18. aug & 223 & 2.17 & $1.19(55 \%)$ & 28.3 & 55.0 & 40.8 \\
\hline
\end{tabular}

${ }^{1}$ In 2001 we observed mass occurrences in Lake Brisketjørna, a neighboring lake $3 \mathrm{~km}$ south of Lake Sandvatn. 


\section{The significance of Bibio pomonae in the fish stomachs}

On five occasions (2004, 2007, 2010, 2013 and 2016) there have been mass occurrences of $B$. pomonae resulting in significant dietary changes of the brown trout in Lake Sandvatn (Table 1). In 2001 the lake was fished for only one night and no $B$. pomonae was observed in the stomachs from Lake Sandvatn. However, in this year mass swarming was observed at the Lake Brisketjørna $3 \mathrm{~km}$ south of Lake Sandvatn.

The mean total stomach fullness in mid-August (Table 1) was 1.52 (min. 0.75 in 2005, max. 2.46 in 2010). Without B. pomonae the mean stomach fullness was 1.32 ( $\min 0.75$ in 2005, max 1.96 in 2002, Figure 4), hence B. pomonae gave a significant positive contribution in years with mass aggregations (paired one-tailed t-test, mean difference \pm SE: $0.20 \pm 0.09, \mathrm{n}=$ $15, p=0.025$ ). The brown trout obviously continue its ordinary search for food in years with mass occurrences of $B$. pomonae, but in periods with easily available $B$. pomonae it constitutes a significant additional food supply.

Lake Sandvatn was not fished in 2003. At this time the strong year class of 1997 resulted in a dense population, depressing food availability with low stomach fullness. This situation lasted until 2007 when the population density normalized (Rognerud \& Qvenild 2016).

In years with mass aggregations, the density of $B$. pomonae will vary significantly and swarming flies will have a patchy distribution. The availability to the brown trout is also strongly dependent on the weather. In 2016 days 1 - 2 were dominated by cold and windy weather with an abrupt shift to sunny, warm and calm weather on days 3 - 5 (Table 2, Figure 5). The same pattern was noticed in 2010 .

Under favorable conditions the brown trout stomach fullness with $B$. pomonae can be an indicator of the abundance of $B$. pomonae. The last three days in 2016 B. pomonae completely dominated the food supply (Figure 5). This was also reflected in the frequency of brown trout eating B. pomonae (Table 2).

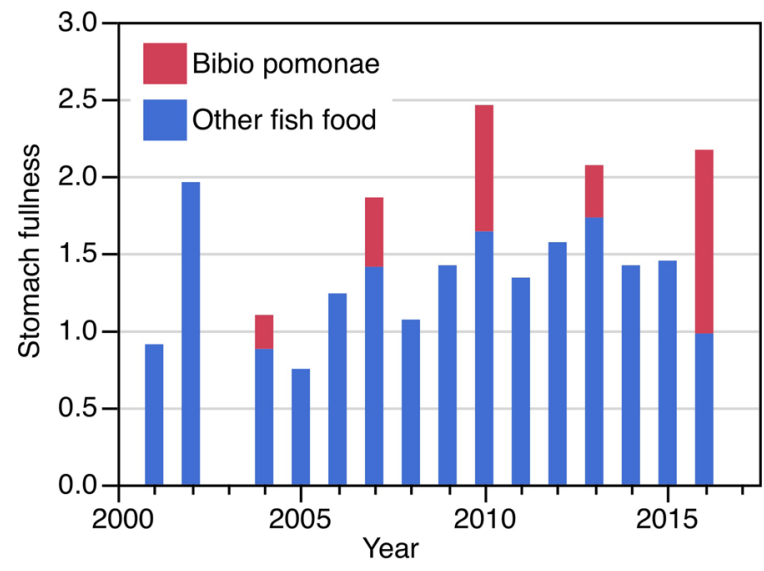

Figure 4. Stomach fullness in brown trout in Lake Sandvatn in the period 2001-2016 (no records in 2003). The contribution from Bibio pomonae was significant in 2004, 2007, 2010, 2013 and 2016.

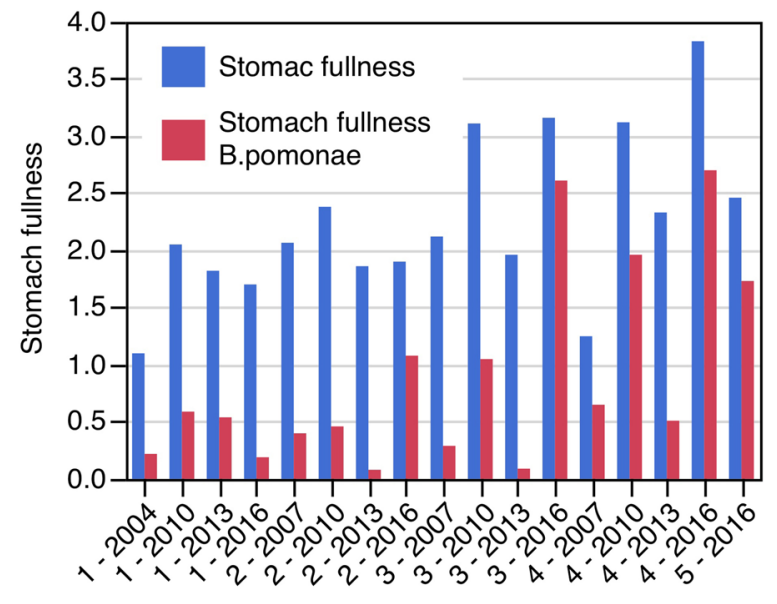

Figure 5. Total stomach fullness in the brown trout compared to brown trout stomach fullness with Bibio pomonae.

There will be variations in the availability of $B$. pomonae for brown trout predation as shown by the day by day consumption (Table 2). Obviously, the weather conditions are crucial but also the availability of $B$. pomonae will be a significant factor. If we use the contribution of $B$. pomonae to the stomach fullness integrated through the test fishing period 14 -18 August, 2016 peaks out as a strong year where B. pomonae contribute for $55 \%$ of the total food supply (Table 1). The many reports of mass aggregations also reflect 2016 as a year where $B$. pomonae was highly abundant. Also in 2010 the mass occurrence seems to be strong. In these two years, the frequency of fish with empty stomachs where at a minimum, emphasizing the significant contribution of $B$. pomonae to brown trout feeding.

Summarized, it seems that stomach fullness of $B$. pomonae gives a good measure of the availability of $B$. pomonae. As pointed out in Table 2, the fraction of fish with $100 \% B$. pomonae in the stomachs increases with availability, hence the brown trout gets more selective to $B$. pomonae with an increased availability. However, it seems to be a threshold between 2016 and the further occasions: with an enhanced availability as in 2016 the brown trout gets more selective, at lower levels the selectivity seems fairly constant.

\section{The 2016 survey}

We received 83 reports from all parts of Norway and some in Sweden, mostly from the southern part of Norway where mass swarming occurred (68 reports, Figure 6). Skartveit (1995) reviewed all material available in Norwegian museums in addition to some material collected by the author. Hence he has identified the species different to the records collected here with questionnaires. B. pomonae is quite conspicuous due to its large size, long legs and bright red femorae. Unskilled persons are thus able to recognize the species with a short introduction, especially when forming mass aggregations (Skartveit \& Greve 1995). We therefore assume most of the records to be correct although $B$. pomonae might be confused with red legged 
Table 2. Daily captures of brown trout in years with Bibio pomonae. From the total stomach fullness and the volume $\%$ of $B$. pomonae, the stomach fullness of $B$. pomonae is computed. In the last column, the number of fish with $100 \%$ B. pomonae in the stomachs are given.

\begin{tabular}{|c|c|c|c|c|c|c|c|c|}
\hline & Date & $\begin{array}{c}\text { No with } \\
\text { B. pomonae }\end{array}$ & $\begin{array}{c}\text { Total no } \\
\text { of fish }\end{array}$ & $\begin{array}{l}\text { B. pomonae } \\
\text { frequency } \%\end{array}$ & $\begin{array}{l}\text { Stomach } \\
\text { fullness }\end{array}$ & $\begin{array}{c}\text { B. pomonae } \\
\text { volume } \%\end{array}$ & $\begin{array}{l}\text { Stomach fullness } \\
\text { B. pomonae }\end{array}$ & $\begin{array}{c}\text { No with } \\
\text { B. pomonae } 100 \%\end{array}$ \\
\hline Day $1-2004$ & 16.08 .04 & 6 & 49 & $12 \%$ & 1.1 & 19.6 & 0.22 & $4(67 \%)$ \\
\hline Day $2-2007$ & 12.08 .07 & 13 & 95 & $14 \%$ & 2.4 & 12.8 & 0.31 & $4(31 \%)$ \\
\hline Day $2-2007$ & 13.08 .07 & 9 & 37 & $24 \%$ & 1.73 & 28.1 & 0.49 & $3(33 \%)$ \\
\hline Day $3-2007$ & 14.08 .07 & 5 & 49 & $10 \%$ & 2.12 & 13.5 & 0.29 & $1(20 \%)$ \\
\hline Day $4-2007$ & 15.08 .07 & 34 & 96 & $35 \%$ & 1.25 & 52.1 & 0.65 & $17(50 \%)$ \\
\hline Day $1-2010$ & 08.08 .10 & 25 & 96 & $26 \%$ & 2.05 & 28.7 & 0.59 & $7(28 \%)$ \\
\hline Day $2-2010$ & 09.08 .10 & 10 & 39 & $26 \%$ & 2.38 & 19.2 & 0.46 & $3(30 \%)$ \\
\hline Day $3-2010$ & 10.08 .10 & 6 & 18 & $33 \%$ & 3.11 & 33.8 & 1.05 & $2(33 \%)$ \\
\hline Day $4-2010$ & 11.08 .10 & 23 & 33 & $70 \%$ & 3.12 & 62.8 & 1.96 & $7(30 \%)$ \\
\hline Day $1-2013$ & 11.08 .13 & 7 & 38 & $18 \%$ & 1.82 & 29.4 & 0.54 & $2(29 \%)$ \\
\hline Day $2-2013$ & 12.08 .13 & 1 & 37 & $3 \%$ & 1.86 & 4.3 & 0.08 & $1(100 \%)$ \\
\hline Day $3-2013$ & 13.08 .13 & 2 & 52 & $4 \%$ & 1.96 & 4.5 & 0.09 & $1(50 \%)$ \\
\hline Day 4 - 2013 & 15.08 .13 & 16 & 87 & $18 \%$ & 2.33 & 21.9 & 0.51 & $5(31 \%)$ \\
\hline Day $1-2016$ & 14.08 .16 & 9 & 64 & $14 \%$ & 1.7 & 11.3 & 0.19 & $2(22 \%)$ \\
\hline Day $2-2016$ & 15.08 .16 & 28 & 69 & $41 \%$ & 1.9 & 56.9 & 1.08 & $15(54 \%)$ \\
\hline Day $3-2016$ & 16.08 .16 & 15 & 19 & $79 \%$ & 3.16 & 82.7 & 2.61 & $12(80 \%)$ \\
\hline Day $4-2016$ & 17.08 .16 & 6 & 6 & $100 \%$ & 3.83 & 70.4 & 2.70 & $4(67 \%)$ \\
\hline Day $5-2016$ & 18.08.16 & 33 & 65 & $51 \%$ & 2.46 & 70.5 & 1.73 & $24(73 \%)$ \\
\hline
\end{tabular}

empidids (John Skartveit, pers. comm.). The distribution map of Skartveit (1995) can thus be complemented with 11 new EIS squares $(16,26,34,54,61,69,70,78,80,88,99)$.

The altitude varies from $350 \mathrm{~m}$ a.s.l. in the main valley of Vestre Slidre, to the highest at Lake Øvre Leirungstjørn 1678 $\mathrm{m}$ a.s.l in Jotunheimen. At this extreme altitude B. pomonae occurred in enormous amounts both in the air and in countless clusters on the ground 20 - 25 August (Ove Lien, pers. comm.). In the Jotunheimen area $B$. pomonae were observed flying at altitudes up to $2000 \mathrm{~m}$ a.s.l.

From the reports with positive observations (single species to mass occurrences), 61 can be localized according to the tree line. Although the reports cover most of the mountain range in southern Norway the material may be skewed. However, in the material $41(67 \%)$ records are from the lower alpine zone, $5(8 \%)$ are in the tree line and 14 (23\%) in the subalpine zone. Only one record is from the alpine zone.

The earlier findings considered B. pomonae to reach its maximum abundance in the subalpine zone (Greve et al. 1984; Skartveit 1995). If this is correct, a shift of this distribution pattern apparently has taken place. $B$. pomonae now seems to have extended its maximum abundance into the lower alpine zone as far the most of the present records are from this zone.

We have also received information from the county of Jämtland in Sweden, some dispersed observations of moderate occurrences from Härjedalen and one from the watercourse of Ljungan downstream of Storsjøen 293 m a.s.l. (Ingemar Näslund, pers. comm.). Further south in the county of Värmland no observations are known (Sven-Åke Berglind, pers. comm.).

From Chesire Peak District in UK, two mass aggregation episodes are reported in the $21^{\text {st }}$ century in the end of August, one in 2005 and one in 2007 (Dennis 2008).

\section{Flight period}

The earliest records of B. pomonae in Norway are from 28 June (Skartveit 1995). In 2016 we had a record of some single species 25 June at Lake Dragøyfjorden at the Hardangervidda Mountain plateau $1180 \mathrm{~m}$ a.s.l. (Herman Stakseng, pers. comm.). Despite this very early observation most of July was without records.

6 July the first mass swarming occurred at Lake Syndin 937 $\mathrm{m}$ a.s.l. in the Valdres region. Elsewhere, the mass swarming seems to have started in the last week of July. Throughout August mass aggregations formed regularly with a peak in midAugust (Figure 7).

In an extended study in the lower part of Kvenna the first mass aggregations were recorded at altitudes $924 \mathrm{~m}$ a.s.l. (Hondle), $933 \mathrm{~m}$ a.s.l. (Møsstrond), $1030 \mathrm{~m}$ a.s.l. (Lake Vollevatn) and $1112 \mathrm{~m}$ a.s.l. (Lake Sandvatn) in the period 1 - 7 August. In this first week of August the weather conditions were unstable. As an example, B. pomonae mass swarming was noted only on 2 August in Lake Sandvatn, the only day 


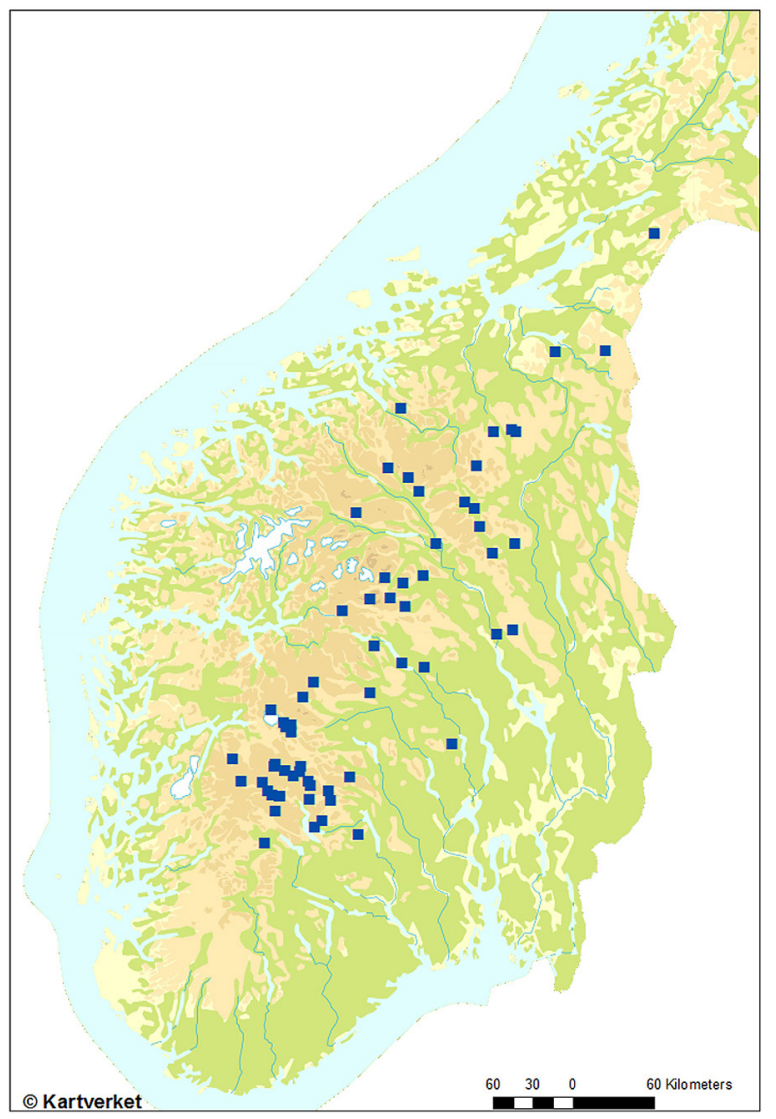

Figure 6. The plot of mass aggregations of Bibio pomonae records in Southern Norway 2016. Most of the records are from the lower alpine zone as indicated on the map. The Norwegian Mapping Authority CC BY 4.0.

with calm and sunny weather (Einar Finøen, pers. comm.). In the week 15 - 21 August the weather condition improved and mass aggregations were seen at all the lakes in the Kvenna river system up to $1170 \mathrm{~m}$ a.s.l. (Lake Litlosvatn). The span in altitude along this river is approximately $250 \mathrm{~m}$ which means a temperature decrease of ca. $2^{\circ} \mathrm{C}$ (see Rognerud et al. 2006). Apparently, there was no tendency of a delayed flight time at higher altitudes in the watercourse of Kvenna. We assume the span in altitude is to limited compared to the species range.

At Litlos tourist station (1170 m a.s.l.) the development of $B$. pomonae were continuously followed from early July to early September by the same skilled person (Jarle Viskjer, pers. comm.). The first records of single specimens were made early in July. An increase in abundance through July to the formation of mass swarming in August was noted. Mass swarming was especially noticed in calm and sunny weather.

In the total material, there are 48 properly dated observations of mass aggregations. In this material, it is a bigger span in altitude indicating a tendency that $B$. pomonae forms mass aggregations later in high altitude areas (Figure 7).

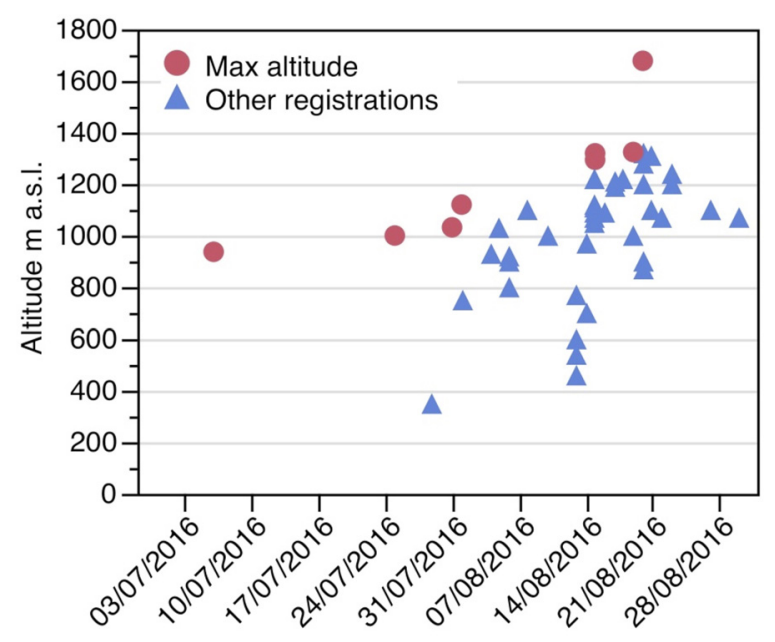

Figure 7. Flight time records for mass aggregations of Bibio pomonae (48 observations) in the southern part of the Norwegian mountain range in 2016. At a given date the maximum altitude is indicated by red filled circle, other registrations with blue filled threesome.

\section{DISCUSSION}

No systematic collecting of mass aggregation events of $B$. pomonae has taken place over large areas in Norway, nor in Sweden. Before 2000 there is only fragmentary information on mass aggregation events. In the $21^{\text {st }}$ century mass aggregations seem to be a more regular phenomenon and more information is available both as reports from anglers and from direct observations of brown trout stomach content.

\section{Stomach fullness as an indicator of mass aggregation of Bibio pomonae}

Bibio pomonae has earlier been recorded from many localities at the Hardangervidda Mountain plateau (Skartveit \& Greve 1995; Skartveit 1995). Hardangervidda is reasonable well covered in this material and the species must be regarded as common to the area. However, no mass aggregations have earlier been reported. In the study of Lake Sandvatn we first observed the phenomena in 2001 at Lake Brisketjørna, a neighboring lake $3 \mathrm{~km}$ south of Sandvatn. Since then, mass aggregations have shown a regular pattern with three year cycles.

As pointed out by Fjellheim et al. (2007) examination of stomach contents of brown trout may be a sensitive method to evaluate the animals occurring in a lake and its surroundings. In the Lake Sandvatn study we assume this to give an adequate measure of the mass aggregation phenomena especially under favorable weather conditions. This was clearly demonstrated in 2016. The first two days, the weather was dominated by cold wind and rain, and B. pomonae contributed less to fish feeding. An abrupt shift to sunny, warm and calm weather showed a basic change where $B$. pomonae totally dominated the food supply. Integrated through the week $14-18$ August $B$. pomonae amounted for $55 \%$ of the food supply. For the last three days 
with optimal flight conditions B. pomonae amounted for $74 \%$. The stomach fullness also increased from 2.17 (the whole period $14-18$ August) to 2.70 (16-18 August). Hence the stomach fullness clearly reflected this event.

From the stomach contents alone It may be difficult to evaluate if the fish became more selective to $B$. pomonae with increasing accessibility. However, as pointed out in Table 2 there seems to be a gap to a higher fraction of fish only eating $B$. pomonae in 2016 than in the preceding years $(63 \%$ in $2016,35 \%$ as a mean for the years 2007, 2010 and 2013). This follows optimal foraging theory which suggests individuals to specialize on optimal prey when prey is abundant (Johansen et al. 2011).

However, it seems to be a threshold between 2016 and the further occasions: with an enhanced availability as in 2016 the brown trout gets more selective, at lower levels the selectivity seems fairly constant.

Reports from the southern part of the Norwegian mountain range showed mostly the same picture. The feeding on $B$. pomonae was so comprehensive that the brown trout were fed to satiation, and rod fishing became ineffective and useless. This phenomenon is earlier described from Sweden on grayling (Andersson 1944). Reports of lake surfaces covered with $B$. pomonae and malodorous shores with dead and dying $B$. pomonae were common. Indeed, there was a powerful mass swarming in 2016, well monitored by the brown trout eating. Also in 2010 the abundance seemed to be strong.

\section{Mass aggregations of Bibio pomonae on the Scandinavian Peninsula}

Adult specimens of $B$. pomonae are easily caught because of their awkwardness and because they quite often are abundant when present. Nevertheless, few researchers have dealt with this species in general and quite a few with the phenomena of mass aggregations. We have searched for information both in scientific journals and the trivial literature.

Before $21^{\text {st }}$ century the mass aggregation phenomena seemed to be fragmentary. The only described events in the $19^{\text {th }}$ century were one incident in Nordland in 1881 and one in a low-land locality in southern Norway in 1883.

We have no records from the cold beginning of the $20^{\text {th }}$ century. After the abrupt shift in temperature in the 1920s some incidents are known. In 1935 and 1938 there was observed heavy mass swarming in Nord-Trøndelag. The event was verified by the Royal Norwegian Society of Sciences and Letters, the Museum (DKNVS, Trondheim). DKNVS received a lot of samples of $B$. pomonae from different parts of the country this year. Earlier years this species should not have been noted, emphasizing that mass aggregations must have been rare in the cold beginning of the century. $B$. pomonae was also observed in the Jotunheimen area in 1938 but not as mass aggregations. It was hypothesized that the cold weather in this southern part compared to the Trøndelag region could be an explanation. An intense mass swarming was reported from northern Sweden in
1944. In 1950 mass swarming was reported from the subalpine region from the southeastern part of Norway.

The following decades of the century we have records from 1968 in northern Sweden, from the western part of the Hardangervidda Mountain plateau in 1972, and one record from Jølster in western Norway and one from Nordland in 1974. In the 1980s mass occurrences are known both from western Norway and from the Trøndelag region. From northern Norway one incident are reported in 1992. Except for these observations few references are available and no pattern can be drawn.

When swarming the $B$. pomonae pays a significant contribution to brown trout feeding. The selectivity for this food item when swarming needs precise fly imitations when fly fishing. In older publications on fish food items $B$. pomonae shows an astonishing absence (Dahl 1913; Sømme 1941; Nordbye undated). This underlines the feeling of mass aggregations of $B$. pomonae being an infrequent event in the $20^{\text {th }}$ century. The statement from DKNVS in 1938 emphasizes this.

B. pomonae is the only bibionid with a traditional Norwegian name, viz. "russeflue" or "the Russian fly" (Skartveit 1995). This is an old name and hence we assume that mass occurrences have been more common in this century as many fishermen and researchers have experienced it, although very few can date it. In the Dovrefjell mountain area Greve et al. (1984) studied distribution and flight period of the Bibionidae family in the period 1980-1983. No mass occurrences were indicated by their Malaise traps but single specimens were evenly caught. Hence, B. pomonae seems to be a commonly distributed species but that mass occurrences needs specially combinations of environmental qualities. Temperature has shown to be a vital statistic for larval development (Skartveit \& Solhøy 1997).

Our studies in Lake Sandvatn in the $21^{\text {st }}$ century showed a regular pattern of mass occurrences every third year since 2001. We therefore searched for verification of similar events in other areas and localities. In 2001 mass swarming was recorded in at least six localities, all in the lower alpine zone in southern Norway. In 2007 B. pomonae was observed in at least five localities, all in the lower alpine zone in southern Norway. In 2010 we have noted six records, in 2013 seven records, all from the subalpine or lower alpine zone in southern Norway. The records from 2001-2013 are all from the subalpine or the lower alpine zone in the central and southern part of Norway. Despite few observations until 2016 there seems to be synchronic mass aggregations throughout central and southern part of Norway the same years in the $21^{\text {st }}$ century. This is emphasized by the extended monitoring in 2016.

From the northern part of Norway and Sweden the information is more restricted. We have records from 2003, 20052008 and 2011. No records were available in 2016 from this part of the Scandinavian Peninsula. This indicate a oneyear delay of development between the southern and northern part of the Scandinavian Peninsula with a shift approximately at $65^{\text {th }}$ latitude (the border between Nord-Trøndelag and Nordland counties). 


\section{Flight period}

Skartveit (1995) noted the earliest records of B. pomonae to be 28 June. In 2016 we have a record of single species from 25 June at Lake Dragøyfjorden at the Hardangervidda Mountain plateau. It is still more remarkable as this is a high-altitude lake (1180 m a.s.l.).

Greve et al. (1984) collected the first B. pomonae 24 July in their Malaise traps at Kongsvoll in the subalpine zone, their latest on 7 September. Further data suggest that the species flies from early July to mid-September, with the number of records peaking in mid-August (Skartveit 1995).

Continuous observations from early July to late August at Litlos tourist station (1170 m a.s.1.) shows a slow development from early July, with formation of mass aggregations in August (Jarle Viskjer, pers. comm.). Litlos are situated high up in the Kvenna watercourse. This apparently contradicts the observations from numerous fishermen lower in this river system where only few observations were made until $B$. pomonae formed mass aggregations in August. This may be due to the weather conditions, low densities and/ or unskilled observers. When swarming, the phenomena seem impossible to neglect. We assume the same explanation useful for the material in total. Thus, single records of species in July seem to be underestimated by the method used.

As noted by Skartveit (1995) there is a tendency that $B$. pomonae fly later in high altitude areas. As pointed out from Litlos there is a continuous development from single species to mass aggregations. We have a total of 48 observations properly dated of mass aggregations of $B$. pomonae from the southern part of the Norwegian mountain range, and in this material, it is a tendency that $B$. pomonae fly later in high altitude areas.

Mass occurrences have been observed as late as 18 September in Folldal at Lake Fundin 1022 m a.s.l. (Bjørn Wegge, pers. comm.).

\section{Regular mass aggregations of Bibio pomonae - an indication of climate change?}

Bibio pomonae is generally distributed and common throughout Norway and Sweden in sparse numbers, but may form mass aggregations (Greve et al. 1984; Skartveit \& Greve 1995; Skartveit 1995). The conditions for mass aggregation formations are not known.

The bibionid larvae are regarded as morphological primitive and are among the most archaic Diptera larvae. The study of bibionid larvae development in the field requires a large collecting effort, and only fragmentary studies have been compiled, all at Hardangervidda Mountain plateau (Skartveit \& Solhøy 1997). The study indicated as many as seven larval instars, and a three to four years' life cycle. Bibionid larvae live in the upper few centimeters of the soil, but they are susceptible to frost and may go deeper (Skartveit \& Solhøy 1995). The study showed a speed up in larval growth rates for Bibio rufipes with increased temperature. This may apply to $B$. pomonae as well. Thus, it can be hypothesized that climatic change, especially with respect to temperature, may play an important role. Climatic conditions, i.e. warm summers, has earlier been pointed out as a driver for mass swarmings of $B$. pomonae (Schøyen 1884; Baashuus-Jessen 1938).

The Vestlandet series 1734-2003 correlates well with the Austlandet series and the Uppsala series, showing an increase in the temperatures in the $20^{\text {th }}$ century (Nordli et al. 2003). The increase in temperature often seems to have occurred in abrupt shifts. Since the last shift in the 1920s the temperature has remained high. A new abrupt shift seems to have established after the millennium shift and the average spring-summers in the period $2000-2016$ is $0.95^{\circ} \mathrm{C}$ higher than the Bergen normal (1961-1990). The abrupt change in climatic conditions on the Hardangervidda Mountain plateau is also reflected at the Hardangerjøkulen glacier with a significant mass deficit since 2000 (www.nve.no/bre). This shift seems to be a general shift for a much broader area, making the mountain ecosystem warmer and more productive.

There have been more frequent and regular mass aggregations after the millennium shift, probably because of a warmer climate. Earlier a change to warmer conditions, also experienced some mass occurrences. Since the thermal shift in the 1920s a mass occurrence was noted in Norway in 1935 and 1938, another in Sweden in 1944. The Royal Norwegian Society of Sciences and Letters identified B. pomonae, and confirmed that such a mass occurrence was unknown from the previous decades (Anon. 1938). The locals made the same statement in 1944 (Andersson 1944). The previous decades of the $20^{\text {th }}$ century was a cold period. All the events later in the $20^{\text {th }}$ century experienced the warmer period after the shift in the 1920s. Thus, the more frequent and regular mass aggregations seen in the $21^{\text {st }}$ century may probably be a result of the new shift to an even warmer climate.

After the mass aggregation events the numerous eggs and produced larvae may have experienced a high degree of survival, resulting in a new mass aggregation three years thereafter. The larvae are phytosaprofagous living mostly on decaying plant material in the upper few centimeters of the soil (Greve et al. 1984; Skartveit 1995; Skartveit \& Solhøy 1997). In the period 2001-2016 the winter conditions have varied extensively. The winter 2011/2012 was cold with only a thin snow shelter. This may have depressed the temperature in the larval zone although the larvae seem able to dig deeper. This severe winter conditions obviously did not injure the larvae as a new mass aggregation formed in 2013. The winter 2014/2015 we experienced heavy snow falls followed by a cold spring and a cold and short summer, probably with decreased larval growth. This may have been compensated in 2016, a long and warm summer with very intense mass swarmings. The other winters are intermediate, and thus the winter conditions do not seem to have affected larval survival significantly. The summer too can be cold, especially 2012 and 2015, both years the summer before mass aggregation events. Thus, the larvae seem to be robust through their development period. A bottle neck may be 
the time of imago hatching (July and August). In 2016, the year with the most intense and widespread mass occurrences, July and August had favorable temperatures.

Bibio pomonae is not regarded as an alpine species in Norway, but is considered as such at more southern latitudes (Pecina 1965 cited in Greve et al. 1984). It generally extends its distribution into the lower alpine zone, but previous records suggest that in the past it had its highest abundance in the subalpine zone (Skartveit 1995). In the 21 $1^{\text {st }}$ century however, $B$. pomonae seems to have its main abundance in the lower alpine zone. In $201667 \%$ of the localities with mass occurrence were in this zone (1000-1400 $\mathrm{m}$ a.s.l.), and the maximum abundance seems to have increased to a higher altitude. The species also appeared earlier in the season than known from previous records (Skartveit 1995).

The highest altitude from which the species have been collected in Norway is $1440 \mathrm{~m}$ a.s.l. but this specimen was most likely blown up from a lower altitude (Skartveit 1995). At a locality near Kongsvoll swarming was noted up to 1360 m a.s.l. (Skartveit op. cit.). In 2016 B. pomonae was seen swarming at Øvre Leirungstjørn in Jotunheimen $1678 \mathrm{~m}$ a.s.l. There were enormous amounts the whole Leirungsdalen valley up to the uppermost lake were the abundance reached its maximum density. The species were noted up to approximately $2000 \mathrm{~m}$ a.s.l. but this may be due to the wind conditions. The abundances seen in the Leirungdalen valley may also have been effected by the wind conditions in this narrow and steep valley. Anyway, there was several days with calm and sunny weather and $B$. pomonae seemed to be noted also in other areas in eastern Jotunheimen. Thus, $B$. pomonae seems to swarm in the alpine zone to a significant higher altitude that seen ever before.

The findings described in this paper indicates that climate change seems to influence mass aggregations, which apparently increase in strength (i.e. 2016), the elevation of the abundance maximum, the new extreme altitude swarming, and the early hatchings seen after 2000 .

\section{ACKNOWLEDGEMENTS}

The authors gratefully acknowledge the Norwegian Environment Agency and Laagefjeld AS for financial support. A special thank is given to Eirik Fjeld for help with the statistics and layout of figures, and Roar Kiær for help with drawing the maps. John Skartveit and an anonymous referee are acknowledged for critically reading and commenting on the manuscript. We will also thank Marte Qvenild for improving the English.

\section{REFERENCES}

Andersson D. 1944. Massförekomst av Bibio pomonae F. Entomologisk Tidsskrift 65: 221-222.

Anon. 1938. Fluesvermen i Tunsjøen. Fiskesport nr. 9-1938: 173. (In Norwegian).

Anon. 1950. Insektsverming over Østlandet. Fiskesport nr. 9-1950: 98. (In Norwegian).

BorgstrømR. 2012.Driftsplan forfisketi Ullensvang statsallmenning 2012-2015. Fellesstyret for Ullensvang statsallmenning. 24 p. (In Norwegian).

Brabrand $\AA$, Saltveit SJ. 2005. Fiskeribiologiske undersøkelser i Pålsbufjorden. Lab. for ferskvannsøkologi og innlandsfiske (LFI). Rapport nr. 237-2005. 30 p. (In Norwegian).

Baashuus-Jessen J. 1938. Iakttagelser under ørretfisket fra 3.-16. juli og 7.-20. august 1938. Fiskesport nr. 10-1938: 183-184. (In Norwegian).

Dahl K. 1913. Laks og ørret. Gyldendalske boghandel, Nordisk Forlag. 184 pp. (In Norwegian).

Dennis RLH. 2008. Population outbreaks and scramble mating in Bibio pomonae (F.) (Dipt., Bibionidae) during two years in the Cheshire Peak District. Entomologist's Monthly Magazine, 130.

DKNVS. 1938. Den zoologiske avdeling. In: Årsberetning for 1938. Det kongelige norske Videnskabers Selskab, Museet. Aktietrykkeriet. Pp. 47-52. (In Norwegian).

Fjellheim A, Tysse Å, Bjerknes V. 2007. Fish stomachs as a biomonitoring tool in studies of invertebrate recovery. Water, Air and Soil Pollution Focus 7: 293-300.

Fjellheim A, Tysse A, Elnan G, Gåsdal O, Stakseng H. 2008. Finprikkauren på Hardangervidda. Statusrapport 2007. LFIUNIFOB, 14 p. (In Norwegian).

Greve L, Solem JO, Olsen A. 1984. Distribution and flight periods of Bibionidae (Dipt.) in the Dovrefjell mountains near Kongsvoll, Central Norway. Fauna Norvegica Ser. , 31: 88-91.

Hynes HBN. 1950. The food of freshwater sticklebacks (Gasterosteus aculeatus and Pygosteus pungitius) with a review of methods used in the studies of the food of fishes. Journal of Animal Ecology 19: 36-58.

Johansen M, Erkinaro J, Amundsen P-A. 2011. The when, what and where of freshwater feeding. In: Aas $\varnothing$, Einum S, Klemetsen A, Skurdal J (eds). 2011. Atlantic Salmon Ecology. Blackwell Publishing Ltd. pp 89-113.

Nordbye L. Undated. Næringsdyr for fisk. Reprint from Norges jeger- $\mathrm{g}$ fiskerforenings tidsskrift. (In Norwegian).

Nordli PØ, Lie Ø, Nesje A, Dahl SO. 2003. Spring-summer temperature reconstruction in western Norway 1734-2003: A data-synthesis approach. International Journal of Climatology 23: $1821-1841$.

Qvenild T. 2016. Endelig en Bibio-sommer? Alt om Fiske nr. 7-2016: 36-38. (In Norwegian).

Qvenild T, Rognerud S. 2013. Lågenvassdraget på Hardangervidda - et klimalaboratorium? Langs Lågen, Årbok 2013 (35. årgang): 99-107. (In Norwegian).

Rognerud S, Borgstrøm R, Qvenild T, Tysse A. 2003. Ørreten på Hardangervidda. NIVA Rapport LNR 4712-2003. 68 p. (In Norwegian).

Rognerud S, Qvenild T, Rakhorst M, Rustadbakken A. 2006. Hardangerviddaprosjektet. Resultater fra undersøkelsen i 2005. 
NIVA Rapport LNR 5181-2006. 35 p. (In Norwegian).

Rognerud S, Qvenild T. 2016. Ørreten på Hardangervidda. Klimaets betydning for årsklassestyrke og produksjon av fisk og næringsdyr i Sandvatn 2001-2015. NIVA. Rapport LNR 69672016. 39 p. (In Norwegian).

Saltveit SJ, Brabrand A. 2008. Fiskeribiologiske undersøkelser i Songa og Bitdalsvatn i 2007. Lab. for ferskvannsøkologi og innlandsfiske (LFI). Rapport nr. 263. (In Norwegian).

Schøyen WM. 1884. Nogle exempler paa insekters masseoptræden i de siste par aar. Entomologisk Tidsskrift 5: 83-87. (In Norwegian).

Skartveit J, Greve L. 1995. Bibionidae (Diptera) from the Hardangervidda. Zoological Museum, University of Bergen, Fauna of the Hardangervidda No. 18.9 p.

Skartveit J. 1995. Distribution and flightperiods of Bibio Geoffroy, 1762 species (Diptera, Bibionidae) in Norway. Fauna Norvegica Ser. B 42: 83-112.

Skartveit J, Solhøy T. 1997. Growth in three species of Bibio (Diptera, Bibionidae) larvae under alpine conditions in Norway. Pedobiologia 41: 263-278.

Sømme ID. 1941. Ørretboka. Jacob Dybwads Forlag. 592 p. (In Norwegian).

Tysse A. 1996. Prikkauren i Svartavatnet og Svartavasstørni. Vasskvalitet, kalking og biologi. Notat. 29 p. (In Norwegian).

Editorial responsibility: Torkild Bakken.

This article is open-access and distributed under the terms of the Creative Commons Attribution 4.0 International license. This permits all non-commercial use, distribution, and reproduction in any medium, provided the original work is properly cited.

(http://creativecommons.org/licenses/by/4.0/). 